\title{
Kocuria palustris sp. nov. and Kocuria rhizophila sp. nov., isolated from the rhizoplane of the narrow-leaved cattail (Typha angustifolia)
}

\author{
Gabor Kovács, ${ }^{1}$ Jutta Burghardt, ${ }^{2}$ Silke Pradella, ${ }^{2}$ Peter Schumann, ${ }^{2}$ \\ Erko Stackebrandt ${ }^{2}$ and Károly Màrialigeti ${ }^{1}$
}

1 Department of Microbiology, Eötvös Loránd University, Budapest, Hungary

2 DSMZ-German Collection of Microorganisms and Cell Cultures $\mathrm{GmbH}$, Mascheroder Weg 16 , 38124 Braunschweig, Germany Author for correspondence: Erko Stackebrandt. Tel: +49531 2616 352. Fax: +49531 2616418.
e-mail: erko@gbf.de

Two Gram-positive, aerobic spherical actinobacteria were isolated from the rhizoplane of narrow-leaved cattail (Typha angustifolia) collected from a floating mat in the Soroksár tributary of the Danube river, Hungary. Sequence comparisons of the 165 rDNA indicated these isolates to be phylogenetic neighbours of members of the genus Kocuria, family Micrococcaceae, in which they represent two novel lineages. The phylogenetic distinctness of the two organisms TA68' and TAGA27' was supported by DNA-DNA similarity values of less than $55 \%$ between each other and with the type strains of Kocuria rosea, Kocuria kristinae and Kocuria varians. Chemotaxonomic properties supported the placement of the two isolates in the genus Kocuria. The diagnostic diamino acid of the cell-wall peptidoglycan is lysine, the interpeptide bridge is composed of three alanine residues. Predominant menaquinone was $\mathrm{MK}-7\left(\mathrm{H}_{2}\right)$. The fatty acid pattern represents the straight-chain saturated iso-anteiso type. Main fatty acid was anteiso- $\mathrm{C}_{15: 0}$. The phospholipids are diphosphatidylglycerol, phosphatidylglycerol and an unknown component. The DNA base composition of strains TA68' and TAGA27' is 69.4 and $69.6 \mathrm{~mol} \%$ $G+C$, respectively. Genotypic, morphological and physiological characteristics are used to describe two new species of Kocuria, for which we propose the names Kocuria palustris, type strain DSM $11925^{\top}$ and Kocuria rhizophila, type strain DSM 11926.

Keywords: Kocuria palustris, Kocuria rhizophila, phylogeny, classification

\section{INTRODUCTION}

The genus Kocuria (Stackebrandt et al., 1995) currently contains four species, i.e. the type species Kocuria rosea, and Kocuria varians, Kocuria kristinae and Kocuria erythromyxa. All were originally placed in the genus Micrococcus. While the first three species had been recognized as individual species, $K$. erythromyxa, strain UWO 1045, was first called 'Sarcina erythromyxa', then recognized as a strain of Micrococcus roseus and subsequently described as Deinococcus erythromyxa, species incertae sedis (Brooks \& Murray, 1981). Following 16S rDNA analysis the Micrococcus

The EMBL accession numbers for the sequences of DSM $11925^{\top}$ and DSM $11926^{\top}$ are $Y 16264$ and $Y 16263$, respectively. species were shown to form an individual cluster within the Arthrobacter-Micrococcus line of descent (Stackebrandt et al., 1980, 1995; Koch et al., 1994); a cluster later described as the family Micrococcaceae (Stackebrandt et al., 1997). Based on 16S rDNA analysis and the presence of a unique pattern of chemotaxonomic properties the three Micrococcus species were transferred to a new genus Kocuria. Later, Deinococcus erythromyxa was added to this genus as $K$. erythromyxa when information on the $16 \mathrm{~S}$ rDNA sequence became available (Rainey et al., 1997). This species is highly related to $K$. rosea, to which it was originally affiliated.

In this communication we report the description of two new species of Kocuria isolated from the rhizoplane of Typha angustifolia in the Danube river. 


\section{METHODS}

Bacterial strains and cultural conditions. Strains TA68 ${ }^{\mathrm{T}}$ and TAGA $27^{\mathrm{T}}$ were isolated from the rhizoplane of the narrowleaved cattail (Typha angustifolia) inhabiting a floating mat on the Soroksár tributary of the Danube river, by plating root mass serially diluted on medium B (Luedeman, 1971) agar plates. The strains were grown on nutrient agar at $28^{\circ} \mathrm{C}$. Strains used for phenotypic comparisons were the type strains of the species Kocuria rosea DSM $20447^{\mathrm{T}}$, Kocuria kristinae DSM $20032^{\mathrm{T}}$ and Kocuria varians DSM $20033^{\mathrm{T}}$. K. erythromyxa DSM $11630^{\mathrm{T}}$ was included in fatty acid analyses.

Media. The following media were used in liquid or semisolid state; nutrient agar consisting $\left(1^{-1}\right)$ of peptone $5 \mathrm{~g}$, meat extract $3 \mathrm{~g}$ and agar (Oxoid) $15 \mathrm{~g}$, adjusted to $\mathrm{pH} 7.0$ and medium $\mathrm{B}$, consisting of starch $20 \mathrm{~g}$, yeast extract $10 \mathrm{~g}$ and agar (Oxoid) $15 \mathrm{~g}$, adjusted to $\mathrm{pH} 7 \cdot 0$.

Morphological studies. Cell and aggregate morphology was studied by phase-contrast microscopy and phase-contrast microphotography of material from surface growth on agar, and by direct observation on the agar surface.

Staining procedures. Gram-staining and acid-fast staining were performed according to Murray et al. (1994).

Physiological characterization. The temperature for all physiological tests was $28^{\circ} \mathrm{C}$ except for studies concerning the temperature range. The relation to oxygen was studied using stab cultures and agar slant cultures placed in an anaerobic chamber. Oxidase activity was checked by the benzidine (Deibel \& Ewans, 1960) and tetramethyl-pphenylendiamine (Tarrand \& Gröschel, 1982) tests. Carbohydrate degradation and acid production from carbohydrates and alcohols was determined via the OF-test according to Hugh \& Leifson (1953) and by use of API $50 \mathrm{CH}$ test strips (bioMérieux). Utilization of various compounds as carbon sources was tested with BIOLOG GPplate, System Release 3.50, following the manufacturer's instructions. Catalase production was demonstrated on slides by the formation of bubbles after mixing a suspension of the organism with a drop of $3 \%(v / v)$ hydrogen peroxide solution. Urease activity, nitrate reduction, aesculin hydrolysis, and hydrolysis of Tween 80 were tested according to published methods (Christensen, 1946; Cowan \& Steel, 1974). Decomposition of an emulsion of UV-sterilized cinefilm strips incubated in phosphate buffer was used to verify gelatin hydrolysis. Casein hydrolysis was determined on streak-inoculated agar mixed from $6 \mathrm{ml}$ liquefied agar and $2 \mathrm{ml}$ steamed skimmed milk, DNA hydrolysis on Bacto DNase test agar (Difco), and hydrolysis of starch on inorganic salts starch agar (Difco) after flooding the agar surface with Lugol's solution containing $0 \cdot 1 \%(\mathrm{w} / \mathrm{v})$ iodine and $0 \cdot 2 \%(\mathrm{w} / \mathrm{v})$ potassium iodide. $\mathrm{H}_{2} \mathrm{~S}$ production was determined as described by Cowan \& Steel (1974). $\mathrm{NaCl}$ tolerance was checked by adding $\mathrm{NaCl}$ to nutrient broth at final concentrations of 2, 5, 7.5, 10 and $15 \%(\mathrm{w} / \mathrm{v})$ of $\mathrm{NaCl}$. Antibiotic resistance tests were performed by measuring diameters of inhibition zones on Mueller-Hinton agar plates containing antibiotic disks (SANOFI Diagnostic, Pasteur).

Chemotaxonomic characterization. Purified cell-wall preparations were obtained as described by Schleifer \& Kandler (1972). Amino acids and peptides in cell-wall hydrolysates were analysed by two-dimensional TLC on cellulose plates using the solvent systems described by Schleifer \& Kandler (1972). The molar ratios of cell-wall amino acids were determined by GC and GC-MS of $N$-heptafluorobutyryl amino acid isobutyl esters (MacKenzie, 1987). Cellular fatty acids extracted according to Korn-Wendisch et al. (1989) were analysed by GC (Groth et al., 1996). Menaquinone profiles were examined by HPLC (Stackebrandt et al., 1995). Polar lipids were extracted as described by Minnikin et al. (1979) and identified by two-dimensional TLC followed by spraying with specific reagents (Collins \& Jones, 1980).

DNA isolation and determination of $\mathbf{G}+\mathbf{C}$ content of DNA. The DNA was isolated as described by Cashion et al. (1977). The $\mathrm{G}+\mathrm{C}$ content of the DNA was determined by highperformance liquid chromatography as described by Mesbah et al. (1989).

DNA-DNA hybridization. DNA hybridization was carried out according to De Ley et al. (1970) with modifications as described by Huß et al. (1983) and Escara \& Hutton (1980) using a Gilford System 2600 spectrophotometer equipped with a Gilford 2527-R thermoprogrammer and plotter. Renaturation rates were computed by the program TRANSFER.BAS (Jahnke, 1992).

16S rDNA sequence determination and phylogenetic analysis. Genomic DNA extraction, PCR mediated amplification of the 16S rDNA and sequencing of the PCR products were as described by Rainey et al. (1996). The sequence reaction products were electrophoresed using a model 373A automatic DNA sequencer (Applied Biosystems). The 16S rDNA sequences were manually aligned with those of members of the class Actinobacteria using the ae 2 editor (Maidak et al., 1996). Evolutionary distances were calculated by the method of Jukes \& Cantor (1969). Phylogenetic dendrograms were reconstructed using the treeing algorithm of De Soete (1983).

Nucleotide sequence accession numbers. Accession numbers for sequences used in the construction of the phylogenetic tree are: Kocuria rosea DSM $20447^{\mathrm{T}}$, X87556; Kocuria varians DSM 20033 ${ }^{\mathrm{T}}$, X87754; Kocuria kristinae DSM $20032^{\mathrm{T}}$, X80749; Kocuria erythromyxa ATCC 187 ${ }^{\mathrm{T}}$, Y11329; Nesterenkonia halobia DSM 20541 ${ }^{\mathrm{T}}$, X80747; Stomatococcus mucilaginosus DSM 20746 ${ }^{\mathrm{T}}$, X87756; Rothia dentocariosa ATCC 19931 ${ }^{\mathrm{T}}$, M59055; Dermacoccus nishinomiyaensis DSM 20448 ${ }^{\mathrm{T}}$, X87757; Kytococcus sedentarius DSM $20547^{\mathrm{T}}$, X87755 and Rubrobacter radiotolerans JCM $2153^{\mathrm{T}}$, U65647. The 16S rDNA sequence of Micrococcus luteus was retrieved from the Ribosomal Database Project (Maidak et al., 1996).

\section{RESULTS AND DISCUSSION}

\section{Cultural characteristics}

Optimal growth for strains TA68 ${ }^{\mathrm{T}}$ and TAGA $27^{\mathrm{T}}$ was obtained on nutrient agar at $28^{\circ} \mathrm{C}$ under aerobic conditions and visible growth was observed $12 \mathrm{~h}$ after inoculation. Colonies were opaque, smooth with irregular edges, and yellow and pale-yellow pigmentation for strains $\mathrm{TA}^{2} 68^{\mathrm{T}}$ and TAGA2 $27^{\mathrm{T}}$, respectively. Temperature range for growth on nutrient agar was between 10 and $40^{\circ} \mathrm{C}$ for strain TA $68^{\mathrm{T}}$ and between 10 and $30^{\circ} \mathrm{C}$ for strain TAGA $27^{\mathrm{T}}$. Strain TAGA $27^{\mathrm{T}}$ grew in up to $7 \%(\mathrm{w} / \mathrm{v}) \mathrm{NaCl}$, while strain TA68 ${ }^{\mathrm{T}}$ grew well at $10 \% \mathrm{NaCl}$, sparsely at $15 \% \mathrm{NaCl}$, but no growth was detected above $15 \% \mathrm{NaCl}$. Both strains grew well between $\mathrm{pH} 5 \cdot 7-7 \cdot 5$, but growth was very poor at pH 8.0 and no growth occurred at $\mathrm{pH} 4.5$ or 8.5 . Growth was never observed under anaerobic conditions. 
Table 1. Phylogenetic distance as determined by 165 rDNA analysis (upper right triangle) and DNA-DNA similarities as determined by hybridization (lower left triangle) of the isolates and three type strains of the genus Kocuria

\begin{tabular}{|c|c|c|c|c|c|}
\hline Taxon & Strain TAGA27 ${ }^{\mathrm{T}}$ & Strain TA68 & K. varians & K. kristinae & K. rosea \\
\hline Strain TAGA2 $27^{\mathrm{T}}$ & - & 97.0 & $96 \cdot 9$ & $95 \cdot 8$ & $97 \cdot 0$ \\
\hline Strain TA68 ${ }^{\mathrm{T}}$ & $30 \cdot 8$ & - & $98 \cdot 6$ & $95 \cdot 8$ & 96.9 \\
\hline K. varians & $42 \cdot 2$ & $52 \cdot 6$ & - & 95.8 & $96 \cdot 6$ \\
\hline K. kristinae & $37 \cdot 0$ & $46 \cdot 6$ & $44 \cdot 0$ & - & $95 \cdot 7$ \\
\hline K. rosea & $46 \cdot 3$ & $43 \cdot 0$ & ND & $34 \cdot 4$ & - \\
\hline
\end{tabular}

ND, Not determined.

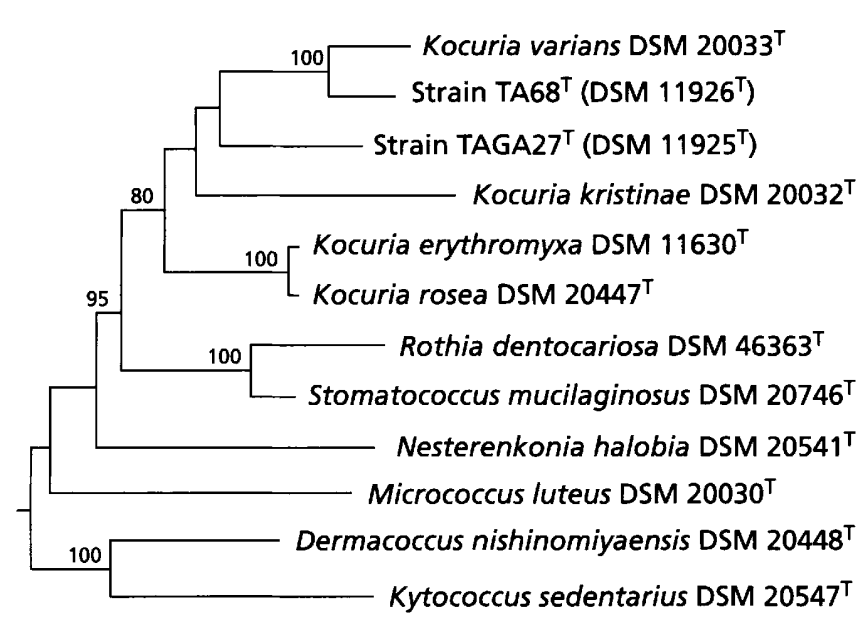

$1 \%$

Fig. 1. $16 \mathrm{~S}$ rDNA sequence based phylogenetic dendrogram constructed from evolutionary distances (De Soete, 1983) showing the phylogenetic position of isolates $\mathrm{TA68}^{\top}$ and TAGA2 $7^{\top}$ within the radiation of Kocuria species. Numbers at branching points refer to bootstrap values $(500$ trees resampled). Scale bar, inferred nucleotide substitutions per 100 nucleotides.

\section{Maintenance}

Serial transfers were done at 4-week intervals on nutrient agar followed by storage at $4{ }^{\circ} \mathrm{C}$. Long-term preservation was achieved by freeze-drying, and maintenance in the vapour phase above liquid nitrogen.

\section{Morphological characteristics}

On nutrient agar the cells of TA68 ${ }^{\mathrm{T}}$ and TAGA $27^{\mathrm{T}}$ were spherical (1.0-1.5 $\mu \mathrm{m}$ in diameter), occurring in pairs, tetrads and packets. Rarely, larger cells $2.0 \mu \mathrm{m}$ in diameter were also found. Cells were non-motile. Endospores were not detected.

\section{Staining reactions}

Strains TA68 ${ }^{\mathrm{T}}$ and TAGA27 ${ }^{\mathrm{T}}$ stained Gram-positive and no lysis was observed following treatment with $3 \%(\mathrm{w} / \mathrm{v}) \mathrm{KOH}$. Cells were not acid-fast.

\section{Phylogenetic analysis}

Almost complete $16 \mathrm{~S}$ rDNA sequences comprising 1447 nucleotides for strain TAGA27 ${ }^{\mathrm{T}}$ and 1471 nucleotides for strain TA68 ${ }^{\mathrm{T}}[95 \cdot 1$ and $95.3 \%$, respectively, of the Escherichia coli sequence according to Brosius et al. (1978)] were determined. Similarity values were calculated for these strains and a representative selection of actinomycete species (not shown). The similarity value between the two strains was $97.6 \%$, while the similarity values determined for the two strains and their closest relatives, which were the type strains of members of the genus Kocuria ranged between 95.8 and $98.6 \%$ (Table 1, upper-right triangle). The two isolates contained all the signature nucleotides that define the family Micrococcaceae to which the genus Kocuria belongs phylogenetically

Table 2. Fatty acid composition of the isolates and the type strains of the genus Kocuria

\begin{tabular}{|c|c|c|c|c|c|c|c|c|c|c|c|c|c|c|c|}
\hline \multirow[t]{2}{*}{ Taxon } & \multicolumn{15}{|c|}{ Fatty acid composition $(\%)^{\star}$} \\
\hline & $\mathrm{i}-\mathrm{C}_{14: 0}$ & $\mathrm{C}_{14: 0}$ & $\mathrm{i}-\mathrm{C}_{15: 0}$ & ai- $C_{15: 0}$ & $\mathrm{C}_{15: 0}$ & $C_{15: 1}$ & $\mathrm{i}-\mathrm{C}_{16: 0}$ & $C_{16: 0}$ & $C_{16: 1}$ & $\mathrm{i}-\mathbf{C}_{17,0}$ & ai- $C_{17: 0}$ & ai- $C_{17: 1}$ & $\mathrm{i}-\mathrm{C}_{18: 1}$ & $\mathrm{C}_{18: 1}$ & $\mathrm{C}_{\mathrm{t}: 2: 2}$ \\
\hline TA $68^{\mathrm{T}}$ & $1 \cdot 1$ & $2 \cdot 4$ & $13 \cdot 8$ & $48 \cdot 4$ & & & 5.9 & $2 \cdot 6$ & & $1 \cdot 2$ & $21 \cdot 1$ & & & & \\
\hline TAGA $27^{T}$ & $2 \cdot 2$ & $3 \cdot 1$ & 1.0 & $59 \cdot 2$ & & 1.0 & $3 \cdot 3$ & $2 \cdot 1$ & & & 9.7 & 3.0 & $4 \cdot 6$ & & $1 \cdot 4$ \\
\hline K. kristinae & 2.6 & 1.0 & 1.6 & $70 \cdot 1$ & & $12 \cdot 1$ & 1.7 & & & $9 \cdot 3$ & & & & & \\
\hline K. varianst & 1.4 & 2.9 & $1 \cdot 3$ & $60 \cdot 3$ & $1 \cdot 3$ & & $11 \cdot 1$ & 9.6 & & & $12 \cdot 1$ & & & & \\
\hline K. rosea $\dagger$ & 1.8 & 1.5 & $7 \cdot 6$ & $70 \cdot 9$ & & & 1.6 & 1.6 & 5.9 & & $4 \cdot 3$ & 3.0 & & & \\
\hline K. erythromyxa & 1.2 & 1.8 & $14 \cdot 1$ & 63.9 & & & 1.4 & 1.2 & 6.7 & & $2 \cdot 4$ & 1.9 & & 1.4 & \\
\hline
\end{tabular}

*Values less than $1 \%$ not shown. $\mathrm{i}$, iso; ai, anteiso.

† Data from Stackebrandt et al. (1995). 
Table 3. Differentiation of the isolates from Kocuria species based on biochemical and physiological characteristics

+ , Positive; $(+)$, weak positive; - , negative.

\begin{tabular}{|c|c|c|c|c|c|}
\hline Physiological reaction & TA68 $\mathbf{T}$ & TAGA27 ${ }^{\mathrm{T}}$ & K. varians* & K. kristinae* & K. rosea* \\
\hline Gelatinase & + & - & + & $(+)$ & - \\
\hline Oxidase & - & - & - & $-f$ & - \\
\hline Starch hydrolysis & - & - & - & - & + \\
\hline Growth on Simmons' citrate & + & - & $(+)$ & - & - \\
\hline Urease & - & + & + & - & - \\
\hline Phosphatase & + & - & - & - & - \\
\hline Tween 80 hydrolysis & + & - & - & - & - \\
\hline Aesculin hydrolysis & - & - & - & + & $(+)$ \\
\hline Arginine dihydrolase & - & - & - & - & - \\
\hline $\mathrm{H}_{2} \mathrm{~S}$ production & $(+)$ & $(+)$ & - & - & - \\
\hline $\mathrm{NO}_{2}^{-}$from $\mathrm{NO}_{3}^{-}$ & - & + & - & - & + \\
\hline \multicolumn{6}{|l|}{ Growth in presence of: } \\
\hline $10 \% \mathrm{NaCl}$ & + & - & - & + & - \\
\hline $15 \% \mathrm{NaCl}$ & $(+)$ & - & - & - & - \\
\hline \multicolumn{6}{|l|}{ Acid production from: } \\
\hline D-Mannose & + & - & + & + & - \\
\hline Galactose & - & + & - & - & - \\
\hline Lactose & - & + & $+\dagger$ & - & - \\
\hline Maltose & - & - & - & + & - \\
\hline Saccharose & + & + & - & + & - \\
\hline D-Xylose & - & - & - & - & + \\
\hline L-Arabinose & - & - & - & - & + \\
\hline Glycerol & - & - & - & + & - \\
\hline Mannitol & - & - & - & - & + \\
\hline Sorbitol & - & - & - & + & - \\
\hline Arbutin & - & - & - & + & - \\
\hline Salicin & - & - & - & + & - \\
\hline Trehalose & - & - & - & + & - \\
\hline Melezitose & - & - & - & + & - \\
\hline Amidon & - & - & - & + & - \\
\hline D-Turanose & - & - & - & + & - \\
\hline Ribose & - & - & + & - & - \\
\hline$\beta$-Gentiobiose & - & - & + & - & - \\
\hline \multicolumn{6}{|l|}{ Utilization of: } \\
\hline Dextrin & + & - & + & + & - \\
\hline Glycogen & + & - & + & + & - \\
\hline Tween 40 & + & + & + & + & - \\
\hline Tween 80 & + & + & + & + & - \\
\hline$N$-Acetyl-D-galactosamine & - & - & - & + & - \\
\hline$N$-Acetyl-D-glucosamine & + & - & - & - & - \\
\hline Adonitol & + & + & + & + & - \\
\hline L-Arabinose & + & - & + & + & + \\
\hline L-Fucose & + & - & + & + & + \\
\hline meso-Inositol & - & - & - & + & - \\
\hline Maltose & - & - & + & + & - \\
\hline D-Mannitol & - & - & - & + & + \\
\hline D-Mannose & + & - & + & + & + \\
\hline D-Melibiose & - & - & + & - & - \\
\hline Sorbitol & - & - & + & + & + \\
\hline Turanose & + & - & + & + & \\
\hline Xylitol & + & - & + & + & - \\
\hline Methyl-pyruvate & + & - & + & - & - \\
\hline Inosine & - & + & + & - & - \\
\hline Glycerol & - & - & - & + & + \\
\hline L-Glutamic acid & - & - & - & + & - \\
\hline L-Alanine & - & - & - & + & - \\
\hline
\end{tabular}

* Data from Stackebrandt et al. (1995).

$\dagger$ Reaction different from published data (Stackebrandt et al., 1995). 
(Stackebrandt et al., 1997). The phylogenetic dendrogram shown in Fig. 1 was constructed from evolutionary distances by the distance matrix method (De Soete, 1983). The 16S rDNA sequence of Rubrobacter radiotolerans was used to determine the root. A total of 1350 nucleotides present in all strains between positions 41 and 1458 (E. coli positions) were used for the analysis. Strains TA68 ${ }^{\mathrm{T}}$ and TAGA $27^{\mathrm{T}}$ grouped amongst species of the genus Kocuria. While strain TA $68^{\mathrm{T}}$ was a phylogenetic neighbour of $K$. varians (98.6\% sequence similarity), strain TAGA2 $7^{\mathrm{T}}$ was more distinct, showing between 95.8 and $97 \%$ sequence similarity to representatives of Kocuria.

\section{DNA-DNA hybridization}

To verify the phylogenetically distinct position of

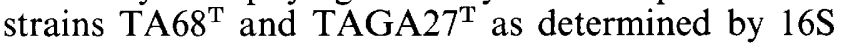
rDNA sequence analysis, the degree of DNA-DNA similarity was determined for these two strains and the type strains of three Kocuria species (Table 1, lower left triange). $K$. erythromyxa was not included because, on the basis of the high 16S rDNA similarity, it can be considered a close relative of $K$. rosea. The DNA -DNA similarity values obtained confirmed the slightly higher degree of relatedness between strain TA68 ${ }^{\mathrm{T}}$ and $K$. varians DSM ( $52.6 \%$ similarity) but all DNA similarities were clearly below $70 \%$ which is considered to be the threshhold value for the delineation of genospecies (Wayne et al., 1987).

\section{Chemotaxonomic characteristics}

Strains TA68 ${ }^{\mathrm{T}}$ and TAGA $27^{\mathrm{T}}$ contained the peptidoglycan amino acids Lys, Glu and Ala at the molar ratio $1 \cdot 2: 1 \cdot 0: 4 \cdot 5$. From this ratio and from the occurrence of characteristic peptides in the partial hydrolysates of cell walls (data not shown), it was concluded that both strains displayed variation A $3 \alpha$ (Schleifer \& Kandler, 1972) with three Ala residues as the interpeptide bridge. The isoprenoid quinones of strain TA68 ${ }^{\mathrm{T}}$ were

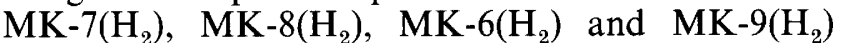
(peak area ratio, 51:39:4:1). Strain TAGA2 $^{\mathrm{T}}$ contains the menaquinones MK-7 $\left(\mathrm{H}_{2}\right), \mathrm{MK}-6\left(\mathrm{H}_{2}\right)$ and MK-8 $\left(\mathrm{H}_{2}\right)$ (peak area ratio, 87:7:2). The polar lipid patterns of both strains consisted of phosphatidylglycerol, diphosphatidylglycerol and one unknown phospholipid. Additionally, strain TA $68^{\mathrm{T}}$ contained one and strain TAGA $27^{\mathrm{T}}$ contained three unknown glycolipids. The cellular fatty acid profiles of both strains were of the branched-chain saturated isoanteiso type and showed anteiso- $\mathrm{C}_{15: 0}$ as the predominating component (Table 2). Strain TA68 ${ }^{\mathrm{T}}$ is characterized by the additional occurrence of anteiso$\mathrm{C}_{17: 0}$ and iso- $\mathrm{C}_{15: 0}$ in high amounts. By comparison, the type strains of $K$. rosea and $K$. erythromyxa both have fatty acid profiles with remarkably high amounts of iso- $C_{15: 0}$ and $C_{16: 1}$ fatty acids. The latter fatty acid could not be detected in the profiles of the other Kocuria species (Table 2).

\section{Physiological characteristics}

For comparison, the type strains of $K$. rosea, $K$. varians and $K$. kristinae were included in the determination of physiological properties of TA68 $8^{\mathrm{T}}$ and TAGA $27^{\mathrm{T}} . K$. erythromyxa was not included because of its high phylogenetic relatedness to $K$. rosea (Fig. 1). Except for two reactions, the physiological tests of the type strains of the three Kocuria species gave results identical with those published in the literature (summarized by Stackebrandt et al., 1995). The two differences were a negative oxidase reaction in $K$. kristinae strain DSM $20032^{\mathrm{T}}$, and acid production from lactose in $K$. varians strain DSM $20033^{\mathrm{T}}$.

Strains TA $68^{\mathrm{T}}$ and TAGA $27^{\mathrm{T}}$ shared the following physiological properties with strains of the other three Kocuria species studied: growth under strictly aerobic conditions; benzidine and catalase tests and growth on inorganic nitrogen were positive; indole-negative, oxidase test and phenylalanine deaminase reaction were negative; acid production from $\mathrm{D}$-glucose and $\mathrm{D}$ fructose; utilization of cellobiose, D-trehalose and glucuronamide was negative. The results of physiological tests in which the isolates differed from each other and/or from the type strains of three species of Kocuria are shown in Table 3.

Susceptibility tests to antibiotics gave the following results: the two isolates and the type strains of the three species of Kocuria were susceptible to penicillin, sulbactam/ampicillin, amoxicillin, piperacillin, meropenem, cefalexine, cefamandol, cefoperasone, chloramphenicol, erythromycin, clindamycin, netilmycin, vancomycin, trimethroprim; all strains were resistant to nitrofurantoin. Strain TA68 ${ }^{\mathrm{T}}$ was resistant to ciprofloxacin while strain $\mathrm{TAGA} 27^{\mathrm{T}}$ was moderately sensitive.

\section{Description of two new Kocuria species}

Phylogenetic and chemotaxonomic evidence indicate that the two isolates from the rhizoplane of Typha angustifolia represent two new lineages within the genus Kocuria. Low to moderate DNA-DNA reassociation values obtained for the two isolates and between them and the type strains of the three of the four currently recognized Kocuria species confirm their species status. Differentiation of the two new species from each other and from the other Kocuria species (little information is available for the moderately radiation-resistant species $K$. erythromyxa; Brooks \& Murray, 1981) is achieved by the primary structure of 16S rDNA, composition of fatty acids (Table 2) and physiological properties (Table 3 ).

\section{Description of Kocuria palustris sp. nov.}

Kocuria palustris (pa.lus'tris. L.fem. adj. palustris marshy, swampy).

The cells are spherical, occurring in pairs, tetrads and packets, $1.0-1.5 \mu \mathrm{m}$ in diameter, Gram-positive and 
non-motile. Endospores not produced. Not acid-fast. The colonies are pale-yellow, $2 \cdot 0-3 \cdot 0 \mathrm{~mm}$ in diameter, opaque, smooth with irregular edges with pale-yellow pigmentation. Aerobic. Chemo-organotrophic. No growth above $30^{\circ} \mathrm{C}$. Good growth at $\mathrm{pH} 5 \cdot 7-7 \cdot 7$. Catalase, urease benzidine and growth on inorganic nitrogen are positive. Phosphatase, Tween 80 hydrolysis and aesculin hydrolysis are negative. Oxidase, gelatinase, starch hydrolysis, growth on Simmons' citrate, indole, aesculin hydrolysis, arginine dihydrolase and phenylalanine deaminase reaction are negative. $\mathrm{H}_{2} \mathrm{~S}$ reaction weak. Nitrate reduced to nitrite. Acid production from D-glucose, D-fructose, galactose, lactose and saccharose. No acid production from glycerol, mannitol, sorbitol, ribose, D-xylose, Larabinose, D-mannose, maltose, $\beta$-gentiobiose, $\mathrm{D}$ turanose, arbutine, salicine, trehalose, melezitose or amidon. Utilization of adonitol, glucuronamide, inosine, Tween 40 or Tween 80 . No utilization of cellobiose, turanose, xylitol, methyl-pyruvate, dextrin, glycogen, $N$-acetyl-D-glucosamine, D-trehalose, Larabinose, D-fructose, L-fucose, $N$-acetyl-D-galactosamine, meso-inositol, maltose, D-mannitol, Dmannose, D-melibiose, sorbitol, glycerol, L-glutamic acid or L-alanine. Growth at $7 \% \mathrm{NaCl}$, but no growth at $10 \% \mathrm{NaCl}$. Peptidoglycan contains L-lysine as the diagnostic diamino acid. The interpeptide bridge consists of three alanine residues (variation $\mathrm{A} 3 \alpha$ ). The major menaquinone is $\mathrm{MK}-7\left(\mathrm{H}_{2}\right)$. The major fatty acid is ai- $\mathrm{C}_{15: 0}$. Predominant polar lipids are phosphatidylglycerol and diphosphatidylglycerol. The DNA base composition is $69.6 \mathrm{~mol} \% \mathrm{G}+\mathrm{C}$. Isolated from the rhizosphere of Typha angustifolia from a floating mat in the Soroksár tributary of the river Danube, Hungary. The type strain is strain TAGA27 ${ }^{\mathrm{T}}$. It has been deposited at the DSMZ-German Collection of Microorganisms and Cell Cultures as strain DSM $11925^{\mathrm{T}}$.

\section{Description of Kocuria rhizophila sp. nov.}

Kocuria rhizophila (rhi.zo'phi.la. Gr. n. rhiza a root; Gr. adj. philos loving; M.L.adj. rhizophila root-loving).

The cells are spherical, occurring in pairs, tetrads and packets, $1.0-1.5 \mu \mathrm{m}$ in diameter, Gram-positive and non-motile. Endospores not produced. Not acid-fast. The colonies are $1.5-2.5 \mathrm{~mm}$ in diameter, opaque, smooth with irregular edges with yellow pigmentation. Aerobic. Chemo-organotrophic. No growth above $40^{\circ} \mathrm{C}$. Good growth between $\mathrm{pH} 5 \cdot 7-7 \cdot 7$. Catalase, benzidine and growth on inorganic nitrogen positive. Gelatinase, phosphatase, Tween 80 hydrolysis, growth on Simmons' citrate are positive. Oxidase, starch hydrolysis, indol, urease, aesculin hydrolysis, arginine dihydrolase and phenylalanine deaminase reaction are negative. $\mathrm{H}_{2} \mathrm{~S}$ reaction weak. Nitrate not reduced to nitrite. Acid production from D-glucose, D-fructose, Dmannose and saccharose. No acid production from glycerol, mannitol, sorbitol, ribose, D-xylose, Larabinose, galactose, lactose, maltose, $\beta$-gentiobiose, D-turanose, arbutin, salicin, trehalose, melezitose or amidon. Utilization of adonitol, L-arabinose, D-fructose, L-fucose, D-glucose, turanose, xylitol, methylpyruvate, glucuronamide, dextrin, glycogen, Tween 40 , Tween 80 and $N$-acetyl-D-glucosamine. No utilization of cellobiose, D-trehalose, $N$-acetyl-D-galactosamine, meso-inositol, maltose, D-mannitol, Dmelibiose, sorbitol, inosine, glycerol, L-glutamic acid and L-alanine. Good growth at $10 \% \mathrm{NaCl}$. Peptidoglycan contains L-lysine as the diagnostic diamino acid. The interpeptide bridge consists of three alanine residues (variation $\mathrm{A} 3 \alpha$ ). The major menaquinones are MK-7 $\left(\mathrm{H}_{2}\right)$ and MK-8( $\left.\mathrm{H}_{2}\right)$. The major fatty acids are ai- $\mathrm{C}_{17: 0}$, ai- $\mathrm{C}_{15: 0}$ and $\mathrm{i}-\mathrm{C}_{15: 0}$. Predominant polar lipids are phosphatidylglycerol and diphosphatidylglycerol. The DNA base composition is $69.4 \mathrm{~mol} \% \mathrm{G}+\mathrm{C}$. Isolated from the rhizosphere of Typha angustifolia from a floating mat on the Soroksár tributary of the river Danube, Hungary. The type strain is strain TA68 ${ }^{\mathrm{T}}$. It has been deposited at the DSMZ as strain DSM $11926^{\mathrm{T}}$.

\section{REFERENCES}

Brosius, J. M., Palmer, L., Kennedy, P. J. \& Noller, H. F. (1978). Complete nucleotide sequence of the 16S ribosomal RNA gene from Escherichia coli. Proc Natl Acad Sci USA 75, 4801-4805.

Brooks, B. W. \& Murray, R. G. E. (1981). Nomenclature for "Micrococcus radiodurans" and other radiation-resistant cocci: Deinococcaceae fam. nov. and Deinococcus gen. nov., including five species. Int J Syst Bacteriol 31, 353-360.

Cashion, P., Holder-Franklin, M. A., McCully, J. \& Franklin, M. (1977). A rapid method for the base ratio determination of bacterial DNA. Anal Biochem 81, 461-466.

Christensen, W. B. (1946). Urea decomposition as means of differentiating Proteus and paracolon cultures from each other and from Salmonella and Shigella types. J Bacteriol 52, 461-466.

Collins, M. D. \& Jones, D. (1980). Lipids in the classification and identification of coryneform bacteria containing peptidoglycans based on 2,4-diaminobutyric acid. J Appl Bacteriol 48, 459-470.

Cowan, S. T. \& Steel, K. J. (1974). Manual for the Identification of Medical Bacteria, 2nd edn. Cambridge: Cambridge University Press.

Deibel, R. H. \& Ewans, J. B. (1960). Modified benzidine test for the detection of cytochrome-containing respiratory systems in microorganisms. J Bacteriol 79, 356-360.

De Ley, J., Cattoir, H. \& Reynaerts, A. (1970). The quantitative measurement of DNA hybridisation from renaturation rates. Eur J Biochem 12, 133-142.

DeSoete, G. (1983). A least square algorithm for fitting additive trees to proximity data. Psychometrika 48, 621-626.

Escara, J. F. \& Hutton, J. R. (1980). Thermal stability and renaturation of DNA in dimethylsulphoxide solutions: acceleration of renaturation rate. Biopolymers 19, 1315-1327.

Groth, I., Schumann, P., Weiss, N., Martin, K. \& Rainey, F. A. (1996). Agrococcus jenensis gen. nov., sp. nov., a new genus of actinomycetes with diaminobutyric acid in the cell wall. Int $J$ Syst Bacteriol 46, 234-239.

Hugh, R. \& Leifson, E. (1953). The taxonomic significance of fermentative versus oxidative metabolism of carbohydrates by various Gram negative bacteria. J Bacteriol 66, 22-66.

Huß, V. A. R., Festl, H. \& Schleifer, K. H. (1983). Studies on the 
spectrophotometric determination of DNA hybridization from renaturation rates. Syst Appl Microbiol 4, 184-192.

Jahnke, K.-D. (1992). BASIC computer program for evaluation of spectroscopic DNA renaturation data from GILFORD SYSTEM 2600 spectrophotometer on a PC/XT/AT type personal computer. J Microbiol Methods 15, 61-73.

Jukes, T. H. \& Cantor, C. R. (1969). Evolution of protein molecules. In Mammalian Protein Metabolism, pp. 21-132. Edited by H. N. Munro. New York: Academic Press.

Koch, C., Rainey, F. A. \& Stackebrandt, E. (1994). 16S rDNA studies on members of Arthrobacter and Micrococcus: an aid for their future taxonomic restructuring. FEMS Microbiol Lett 123, 167-172.

Korn-Wendisch, F., Kempf, A., Grund, E., Kroppenstedt, R. M. \& Kutzner, H. J. (1989). Transfer of Faenia rectivirgula Kurup and Agre 1983 to the genus Saccharopolyspora Lacey and Goodfellow 1975, elevation of Saccharopolyspora hirsuta subsp. taberi Labeda 1987 to species level, and emended description of the genus Saccharopolyspora. Int J Syst Bacteriol 39, 430-441.

Luedemann, G. H. (1971). Micromonospora coerulea (Jensen 1932) and Micromonospora chalcea (Foulerton 1905) . Int J Syst Bacteriol 21, 248-253.

Mackenzie, S. L. (1987). Gas chromatographic analysis of amino acids as the N-heptafluorobutyryl isobutyl esters. $J$ Assoc Off Anal Chem 70, 151-160.

Maidak, B. L., Olsen, G. J., Larsen, N., Overbeek, R., McCaughey, M. J. \& Woese, C. R. (1996). The Ribosomal Database Project. Nucleic Acids Res 24, 82-85.

Mesbah, M., Premachandran, U. \& Whitman, W. B. (1989). Precise measurement of the $\mathrm{G}+\mathrm{C}$ content of deoxyribonucleic acid by high-performance liquid chromatography. Int $J$ Syst Bacteriol 39, 159-167.

Minnikin, D. E., Collins, M. D. \& Goodfellow, M. (1979). Fatty acid and polar lipid composition in the classification of Cellulomonas, Oerskovia and related taxa. J Appl Bacteriol 47, $87-95$.
Murray, R. G. E., Doetsch, R. N. \& Robinow, C. F. (1994). Determinative and cytological light microscopy. In Methods for General and Molecular Microbiology, pp. 32-33. Edited by P. Gerhardt, R. G. E. Murray, W. A. Wood \& N. R. Krieg. Washington, DC: American Society for Microbiology.

Rainey, F. A., Ward-Rainey, N., Kroppenstedt, R. M. \& Stackebrandt, E. (1996). The genus Nocardiopsis represents a phylogenetically coherent taxon and a distinct actinomycete lineage: proposal of Nocardiopsaceae fam. nov. Int $J$ Syst Bacteriol 46, 1088-1092.

Rainey, F. A., Nobre, M. F., Schumann, P., Stackebrandt, E. \& da Costa, M. S. (1997). Phylogenetic diversity of the deinococci as determined by $16 \mathrm{~S}$ ribosomal DNA sequence comparison. Int $J$ Syst Bacteriol 47, 510-514.

Schleifer, K. H. \& Kandler, O. (1972). Peptidoglycan types of bacterial cell walls and their taxonomic implications. Bacteriol Rev 36, 407-477.

Stackebrandt, E., Lewis, B. J. \& Woese, C. R. (1980). The phylogenetic structure of the coryneform group of bacteria. Zentbl Bakteriol I Abt Orig C 2, 137-149.

Stackebrandt, E., Koch, C., Gvozdiak, O. \& Schumann, P. (1995). Taxonomic dissection of the genus Micrococcus: Kocuria gen. nov., Nesterenkonia gen. nov., Kytococcus gen. nov., Dermacoccus gen. nov., and Micrococcus Cohn 1872 gen. emend. Int J Syst Bacteriol 45, 682-692.

Stackebrandt, E., Rainey, F. A. \& Ward-Rainey, N. L. (1997). Proposal for a new hierarchic classification system, Actinobacteria classis nov. Int J Syst Bacteriol 47, 479-491.

Tarrand, J. J. \& Gröschel, D. H. M. (1982). Rapid, modified oxidase test for oxidase-variable bacterial isolates. $J$ Clin Microbiol 16, 772-774.

Wayne, L. G., Brenner, D. J., Colwell, R. R. \& 9 other authors (1987). International Committee on Systematic Bacteriology. Report of the ad hoc committee on reconciliation of approaches to bacterial systematics. Int J Syst Bacteriol 37, 463-464. 